Dr. sc. Tomislav Dagen, dipl. iur. ${ }^{1}$

Marina Čepo, mag. iur. ${ }^{2}$

\title{
IZBJEGLIČKA I MIGRACIJSKA KRIZA U EUROPSKOJ UNIJI - ZAŠTITA PRAVA NA PRISTUP TERITORIJU ILI ZAŠTITA TERITORIJA?
}

\author{
UDK: $341.43(497.5)$ \\ 314.15-054.73 (4-6 EU) \\ DOI: $10.31141 / z r p f s .2021 .58 .141 .855$ \\ Izvorni znanstveni rad \\ Primljeno: 15. prosinca 2020.
}

Izbjeglička i migracijska kriza koja je svoj vrhunac doživjela 2015. godine u Europskoj uniji, stavila je pred Republiku Hrvatsku brojne sigurnosne izazove, a samim time i pravne/normativne izazove u smislu pravne regulative upravljanja takvom krizom. Relacija odnosa između zaštite prava izbjeglica kada pristupe teritoriju i zaštite teritorija zasigurno je utjecala na (javne) politike Republike Hrvatske (u daljnjem tekstu: Hrvatska), a brojna "kršenja" ljudskih prava pala su u drugi plan iz razloga zaštite drugih prava. Suverenost i zaštita teritorija primarna je potreba svakog društva i svakog značenja državnosti, no znači li to da se taj cilj treba ostvariti pod svaku cijenu i s kojim posljedicama, odnosno u kauzalnoj vezi izbjegličke krize i zaštite teritorija/granica što ima nadnacionalnu važnost? Status izbjeglice sadrži brojna prava koja su zaštićena na međunarodnoj razini Konvencijom o statusu izbjeglica. Upravo takve činjenice prihvaćanja međunarodnopravnih obveza Republike Hrvatske postavljaju ključno pitanje stvaraju li i u kojoj mjeri međunarodnopravne obveze Hrvatske prema izbjeglicama nacionalni ili europski sigurnosni izazov. Migranti, koji su se priključili izbjegličkom valu 2015. godine, nisu nositelji prava na azil i moraju poštovati postavljena europska rješenja za zakonit ulazak i boravak u Uniji. Upravo razlikovanje migranata od izbjeglica u navedenoj krizi bio je najveći problem koji je stvorio brojne opasnosti i izazove za države članice, posebice pogranične države poput Hrvatske. Stoga će se u ovom članku analizirati pravo na azil i pristup sustavu azila u odnosu na prava država članica da zaštite svoj teritorij iz razloga nacionalne sigurnosti na primjeru Hrvatske.

Ključne riječi: izbjeglička i migracijska kriza, zaštita teritorija, pravno-sigurnosni izazovi

1 Dr. sc. Tomislav Dagen, dipl. iur., Sveučilište Josipa Jurja Strossmayera u Osijeku, Akademija za umjetnost i kulturu u Osijeku, tomislav.dagen@aukos.hr, tdagen@net.hr

2 Marina Čepo, mag. iur., asistentica, doktorandica Doktorske škole Europskih studija, Sveučilište J. J. Strrosmayera u Osijeku, Akademija za umjetnost i kulturu u Osijeku, mcepo@uaos.hr 


\section{UVOD}

Pravo na azil jedno je od temeljnih ljudskih prava, garantirano nizom međunarodnih i europskih dokumenata, a prvotno se spominje u Općoj deklaraciji o ljudskim pravima (UN, 1948., čl. 14). Pravo na azil nije subjektivno pravo i ne znači da će svaka osoba ostvariti pravo na azil, ali pravo zatražiti međunarodnu zaštitu jest subjektivno pravo i mora se osigurati svima. Kako bi osoba zatražila azil, mora joj se osigurati pristup teritoriju države u kojoj će podnijeti takav zahtjev. U ovom radu govorit će se o zaštiti prava na pristup teritoriju, odnosno pravu na pristup sustavu azila s jedne strane i zaštiti teritorija i nacionalne sigurnosti određene države s druge strane. Pravo na pristup teritoriju, odnosno sustavu azila, prvi je preduvjet za ostvarivanje prava na azil. Kada se pravo na pristup teritoriju ograniči ili onemogući, povrijeđeno je zapravo niz ljudskih prava izbjeglica. Pravo svake države da samostalno odlučuje tko može pristupiti na njezin teritorij, odnosno pravo države da kontrolira svoje granice jest odraz suvereniteta države, a ujedno i odraz zaštite nacionalne sigurnosti. To pravo ograničeno je međunarodnim i europskim obvezama u smislu zaštite ljudskih prava. Traženje međunarodne zaštite direktno je povezano s pristupom državnom teritoriju, što znači da su države obvezne dozvoliti pristup teritoriju u svrhu pružanja takve zaštite. Stoga će se ovaj rad baviti relacijom odnosa između prava na azil, odnosno pristupa teritoriju i zaštite državnog teritorija te posljedično, kreiranjem politika usmjerenih na normativnu zaštitu nacionalnog interesa i sigurnosti određene države članice Europske unije (u daljnjem tekstu: EU).

Brojne posljedice ostavila je migracijska i izbjeglička kriza nakon 2015. godine, a istovremeno otvorila brojne izazove. Zaštita i sigurnost državnog teritorija postala je primarna težnja država članica, što ponovno otvara nova pitanja o suverenitetu. Postupanje u kriznom razdoblju od rujna 2015. do ožujka 2016. godine, predstavljalo je velik izazov zbog masovnih priljeva izbjeglica, a tome je dodatno doprinijelo brojno priključivanje migranata izbjegličkim valovima. Naime, postupanje prema migrantima i izbjeglicama pretpostavlja dva potpuno različita postupka: pravo na međunarodnu zaštitu osigurava se za izbjeglice, dok se za migrante mora poštovati predviđena procedura za zakonit ulazak i boravak u Uniji. Mnogi su migranti, krijući svoj identitet i državne dokumente, imali namjeru obmanuti države članice da dolaze s područja pogođenih ratom i da ulaze u kategoriju izbjeglica. Manipulacije sustavom takve vrste donijele su brojne sigurnosne izazove za države članice.

Rad će biti podijeljen na dva dijela. U prvom dijelu obuhvatit će se međunarodni i europski pravni okvir po pitanju prava izbjeglica na pristup teritoriju i traženje međunarodne zaštite, a drugi dio analizom utjecaja ili kauzalnošću izbjegličke i migracijske krize 2015./2016. godine u Europskoj uniji na kreiranje politika Hrvatske, usmjerene na normativnu zaštitu nacionalnog interesa i sigurnosti, što ujedno podrazumijeva i zaštitu teritorija. 


\section{PRAVO NA AZIL I PRISTUPANJE TERITORIJU ODREĐENE DRŽAVE KAO PREDUVJET OSTVARIVANJA PRAVA NA PRISTUP SUSTAVU AZILA - MEĐUNARODNI I EUROPSKI PRAVNI ASPEKT - de lege lata}

\subsection{Pravo na azil u međunarodnom i europskom pravu}

Pitanje azila, zbog svoje kompleksnosti i osjetljivosti uređeno je nizom nacionalnih, europskih i međunarodnih dokumenata koji se međusobno isprepliću s ciljem što bolje zaštite i osiguranja ljudskih prava (Goldner Lang, 2017.). Pravo na azil prvotno uređuje Opća deklaracija o ljudskim pravima, propisujući da svatko pred progonom ima pravo zatražiti i dobiti utočište u drugim zemljama (UN, 1948., čl. 14. st. 1). Ono što doktrina prigovara takvoj odredbi jest to što ne ispunjava svoju svrhu u potpunosti upravo jer ne propisuje zabranu vraćanja, a odredbe koje sadrži nemaju formalno obvezujuću pravnu snagu za države. ${ }^{3}$ Postavlja se pitanje što bi se dogodilo kada bi države odbile dodijeliti međunarodnu zaštitu izbjeglici na svom državnom teritoriju, a ne postoji odredba o zabrani vraćanja u tako važnom dokumentu poput Opće deklaracije o ljudskim pravima (Einarsen, 2011: 47). Takvo je određenje bilo nedostatno, a takva praznina bila je popunjena Konvencijom o statusu izbjeglica iz 1951. godine (u daljnjem tekstu: Konvencija iz 1951.), koja nije bila vezana odredbama Opće deklaracije o ljudskim pravima, premda se ponekad na njih pozivala (UN, 1951.). Uz Konvenciju iz 1951., temeljni međunarodni dokument koji štiti prava izbjeglica i obvezuje sve države članice EU-a, s obzirom na to da su sve potpisnice, donesen je i Protokol koji je dopunjuje (UN, 1967.). Konvencija iz 1951. štiti svaku osobu koja se nalazi izvan zemlje svog državljanstva te - zbog osnovanog straha od proganjanja zbog svoje rase, vjere, nacionalnosti, pripadnosti određenoj društvenoj skupini, ili zbog političkog mišljenja - ne može ili zbog straha ne želi prihvatiti zaštitu dotične zemlje, kao i osobe bez državljanstva koje se zbog istih razloga i okolnosti nalaze izvan zemlje prethodnog uobičajenog boravišta, a koje se ne mogu ili se zbog straha ne žele u nju vratiti (UN, 1951., čl. 1. st. 2). Osim toga, propisuje i zabranu kažnjavanja zbog nezakonitog ulaska na državni teritorij države potpisnice s ciljem traženja međunarodne zaštite (UN, 1951., čl. 31. st. 1), te zabranu prisilnog udaljavanja izbjeglica koje zakonito borave na državnom teritoriju potpisnice, osim ako je ugrožena nacionalna sigurnost ili javni red (UN, 1951., čl. 31. st. 1). Načelo non refoulement, propisano člankom 33. st. 1. iste konvencije, propisuje da nijedna država ugovornica ne smije protjerati niti vratiti izbjeglicu, ni na koji način, na područje gdje bi njezin život ili sloboda bili ugroženi. Iz navedenih odredbi, jasno je kako države članice imaju obvezu primiti na državni teritorij sve one koji na tom teritoriju imaju namjeru zatražiti međunarodnu zaštitu.

\footnotetext{
3 Upravo zbog toga jer odredbe Opće deklaracije o ljudskim pravima nemaju pravno obvezujuću snagu, njezine odredbe prenesene su u Međunarodni pakt o građanskim i političkim pravima i Međunarodni pakt o ekonomskim, socijalnim i kulturnim pravima kako bi bile obvezujuće za države potpisnice. Ipak, niti u jednom od navedena dva pakta pravo na azil nije izričito spomenuto, premda je bilo tendencija prema tome u određenom trenutku.
} 
Kako navode Hailbronner i Thym, pravila za ulazak i graničnu kontrolu moraju uvijek biti usklađena prvenstveno s pravima izbjeglica i ljudskim pravima, kao prioritetom za postupanje (Hailbronner, Thym, 2016: 48). Bez pristupa teritoriju, ograničeno je pravo na traženje i dobivanje utočišta u određenoj državi. Takvo stajalište potvrđuje i Vibeke Eggli, smatrajući da, kada se govori o međunarodnoj zaštiti izbjeglica i njihovim ljudskim pravima, prelazak državne granice i pristup njihovu državnom teritoriju, predstavlja preduvjet za ostvarivanje međunarodne zaštite jer je fizička prisutnost na teritoriju odlučujući čimbenik u postupku (Vibeke Eggli, 2002: 17). Konvencija za zaštitu ljudskih prava i temeljnih sloboda (u daljnjem tekstu: EKLJP) ${ }^{4}$ ne izolira pravo na azil u katalogu ljudskih prava (Vijeće Europe, 1950.). Povelja Europske unije o temeljnim pravima (EU, OJC 303, 2007.) u članku 18. izričito garantira pravo na azil uz poštovanje pravila iz Konvencije iz 1951., Protokola te Ugovora o Europskoj uniji i Ugovora o funkcioniranju Europske unije (EU, UFEU, 2007.). To pravo ograničeno je pitanjem nacionalne sigurnosti i javnog reda određene države. Konvencija iz 1951. godine propisuje određene iznimke od primjene načela non refoulment, (UN, 1951., čl. 33. st. 2), ali za razliku od toga, članak 3. EKLJP-a nije podložan ograničavanjima. Posljedično tome, zaštita u smislu članka 3. smatra se apsolutnom. ${ }^{5}$

Stoga, EKLJP ima veliku ulogu u dopunjavanju Konvencije iz 1951. i sukladno tome, utjecaju na postupanje država članica. Deklaracija o teritorijalnom azilu iz 1967. godine navodi što bi to opravdalo ograničavanje izbjegličkih prava (UNGA, 1967.). U članku 3. st. 2. Deklaracije navodi se kako je jedini razlog za ograničavanje izbjegličkih prava, odnosno iznimke od zabrane protjerivanja i prisilnog vraćanja, pitanje nacionalne sigurnosti i sigurnosti stanovništva, poput masovnog priljeva osoba. Nasuprot tome, Sud Europske unije (u daljnjem tekstu: Sud EU), u dva slučaja vezana uz primjenu Uredbe o utvrđivanju kriterija i mehanizama za određivanje države članice odgovorne za razmatranje zahtjeva za međunarodnu zaštitu koji je u jednoj od država članica podnio državljanin treće zemlje ili osoba bez državljanstva (u daljnjem tekstu: Uredba Dublin III), ne uvažava masovni priljev osoba na državnu granicu kao razlog za izvanredne mjere, odnosno iskazuje mišljenje da se Uredba Dublin III neizostavno mora primjenjivati čak i u takvim situacijama (EU, OJ L 180, 2013.). ${ }^{6}$ Zakonik o schengenskim granicama uređuje pitanje zakonitog ulaska i boravka te propisuje uvjete koji su potrebni kako bi se određeni ulazak od strane državljanina treće zemlje smatrao zakonitim (EU, OJ L 77, 2016.). Odstupanja koja se propisuju humanitarnog su karaktera i daju priliku državama članicama da preuzmu obvezu razmatranja zahtjeva za azil podnesenog na njihovu teritoriju.

\footnotetext{
4 Konvencija za zaštitu ljudskih prava i temeljnih sloboda, pročišćeni tekst, MU 18/97, 6/99, 14/2, $13 / 3,9 / 05,1 / 06,2 / 10$.

5 Vidi više: ESLJP - Chahal v. The United Kingdom, 1996., Application No. 22414/93, od 15. studenog 1996., kao i: Saadi v. Italy, 2008., Application No. 37201/06, od 28. veljače 2008.

6 Vidi više: Case c-490/16 A. S. vs. Republic of Slovenia (2017). ECLI: 2017: 585, Case C-646/16 Khadija Jafari and Zainab Jafari vs. Bundesamt für Fremdenwesen und Asyl (2017). ECLI: 2017: 586.
} 
Dr. sc. Tomislav Dagen i Marina Čepo, mag. iur.: Izbjeglička i migracijska kriza u Europskoj uniji... Zbornik radova Pravnog fakulteta u Splitu, god. 58, 3/2021, str. 855-873

\subsection{Pravo na pristup teritoriju}

Pravo na pristup teritoriju zapravo se odnosi na zabranu odbijanja ulaska državljanima trećih zemalja s ciljem traženja azila u određenoj državi. Državljanin treće zemlje ima pravo podnijeti zahtjev za međunarodnu zaštitu i ako je na teritorij određene države ušao na nezakonit način. Konvencija iz 1951. zabranjuje kažnjavanje za nezakonit ulazak člankom 31.:

"Države ugovornice neće izreći kazne zbog nezakonitog ulaska ili boravka na svojem području izbjeglicama koje su došle izravno s područja gdje je ugrožen njihov život ili sloboda u smislu članka 1, a ušle su ili se nalaze na njenom području bez dozvole i pri tom su se bez odgode javile vlastima, te predočile valjane razloge svog nezakonitog ulaska ili boravka."

Konvencija iz 1951. ponekad u svojim odredbama ostaje neodređena i nedosljedna, pa tako člankom 31. propisuje zabranu kažnjavanja izbjeglice koji je ušao ili je prisutan na teritoriju države, a u isto vrijeme člankom 26. osigurava slobodu kretanja izbjeglicama koji se nalaze zakonito na teritoriju države. Zakonit status imaju tražitelji azila i osobe koje ulaze na teritorij, zakonito ili nezakonito, s namjerom podnošenja zahtjeva za azil u toj državi. Migranti, odnosno državljani treće zemlje koji nemaju namjeru tražiti azil na području određene države članice već namjeru ući na područje radi zaposlenja ili iz drugih razloga, moraju poštovati proceduru predviđenu legislativom EU-a vezanu za migracije i boravišne dozvole, kao i ostale uvjete. Pravo na pristup teritoriju, odnosno pravo na pristup sustavu azila, uređeno je i na europskoj razini te Direktiva o zajedničkim postupcima za priznavanje i oduzimanje međunarodne zaštite (u daljnjem tekstu: Direktiva o postupku) nameće obvezu državama članicama da osiguraju pristup postupku, odnosno pristup sustavu azila (EU, SL L 180, 2013/32, čl. 6). Prema članku 3. st. 1. Direktive o postupku, pravna stečevina EU-a o azilu primjenjuje se na sve zahtjeve za međunarodnu zaštitu podnesene na državnom području države članice, uključujući one podnesene na granici, teritorijalnim vodama ili tranzitnim zonama države članice, kao i na ukidanje međunarodne zaštite. Jednako tako Direktivom o utvrđivanju standarda za prihvat podnositelja zahtjeva za međunarodnu zaštitu (u daljnjem tekstu: Direktiva o prihvatu) europski zakonodavac pokušava ujednačiti postupanje država članica prilikom prihvata državljana trećih zemalja na svoje državno područje s ciljem podnošenja zahtjeva za azil (EU, SL L 180, 2013/33). Kako Tsourdi smatra, prava osigurana Direktivom o prihvatu odnose se samo na one koji se nalaze zakonito na teritoriju države članice (Tsourdi, 2016: 271). Upravo to bi značilo da migranti, koji nemaju osnovu za traženje azila niti namjeru da zahtjev podnesu, nisu u tom trenutku zakonito na teritoriju države članice i na njih se ne odnose navedene odredbe.

U izbjegličkoj i migracijskoj krizi 2015. godine, jedan od najvećih problema bio je razlikovati migrante i nositelje prava na međunarodnu zaštitu. Kako Schuster smatra, nije bila rijetkost da se izbjeglice, zbog nefunkcionalnog sustava i prevelikog opterećenja, pretvaraju u neregularne migrante (Schuster, 2011.). Na tragu toga, Pollet ističe kako uz mnoge korake koji čekaju Zajednički europski sustav azila (u 
daljnjem tekstu: CEAS) u bliskoj budućnosti, jedno je od bitnih pitanja za opstanak zajedničkog sustava azila ulaganje napora u osiguravanje sigurnih i zakonitih načina za pristup teritoriju i samim time međunarodnoj zaštiti jer upravo to vidi kao ključni izazov u nadolazećim ponovnim izbjegličkim i migracijskim valovima i kao temu mnogih rasprava na europskoj razini (Pollet, 2016.). Pristup teritoriju, odnosno pristup sustavu azila, vrlo je bitan čimbenik u ostvarivanju prava na azil, ali migranti, koji se nalaze u izbjegličkim valovima zajedno s izbjeglicama, ne ostvaruju to pravo i moraju poštovati proceduru predviđenu u Europskoj uniji za zakonit ulazak i boravak na njezinu teritoriju. U izbjegličkoj i migracijskoj krizi 2015. godine, velik broj ekonomskih migranata priključio se izbjeglicama na putu prema Uniji koji su ponekad, skrivajući svoj identitet, osobne iskaznice, putovnice i ostale dokumente, htjeli obmanuti države članice da se zapravo radi o izbjeglicama. Izbjeglice nisu migranti. Kako Hathaway i Foster smatraju, prepoznavanje izbjegličkog statusa ne čini osobu izbjeglicom, već je ona prepoznata upravo zato jer je izbjeglica, što znači da je čin dodjele izbjegličkog statusa deklaratorne prirode (Hathaway, Foster, 2014.). Pokušaj obmana na državnim granicama država članica od strane migranata koji se predstavljaju kao izbjeglice, zasigurno su utjecale na nacionalne sigurnosti država članica, kao i na to da osobama koje su nositelji prava na međunarodnu zaštitu, otežaju i prolongiraju ostvarivanje prava na nju.

\section{ULOGA I POLOŽAJ REPUBLIKE HRVATSKE KAO POGRANIČNE DRŽAVE EUROPSKE UNIJE U IZBJEGLIČKOJ I MIGRACIJSKOJ KRIZI 2015./2016. - SIGURNOSNI IZAZOV I POSLJEDICE}

U situacijama poput izbjegličke i migracijske krize koja se dogodila u Uniji 2015. godine uz masovni priljev osoba, izazov je u isto vrijeme na visokoj razini štititi ljudska prava i očuvati nacionalnu sigurnost. U trenutku migracijske i izbjegličke krize, aktivirana je Uredba Dublin III koja svojom pravnom naravi nije primjenjiva na masovne migracije i zahtijeva pojedinačan pristup. Ineli-Ciger smatra kako se u migracijskoj i izbjegličkoj krizi trebalo kao odgovor uključiti Direktivu o minimalnim standardima za dodjelu privremene zaštite u slučaju masovnog priljeva raseljenih osoba te o mjerama za promicanje uravnoteženih napora država članica pri prihvatu i snošenju posljedica prihvata tih osoba (EU, SL L 212, 2001.) jer je institut privremene zaštite moćan alat međunarodnog prava i bio bi ključan $u$ definiranju smjernica za države članice koje bi pomogle u ujednačenom postupanju u kriznim situacijama poput masovnog priljeva na državnu granicu (Ineli-Ciger, 2015.). Primjena Uredbe Dublin III u trenutku migracijske i izbjegličke krize u Uniji dovela je do preopterećenja pograničnih država članica, što je opet dovelo do brojnih posljedica. Zatvaranje granica od strane određenih država članica, poput Mađarske i Slovenije, posljedica je nepostojanja solidarnosti među državama članicama i prirodne potrebe za zaštitu nacionalnih interesa i sigurnosti. Migracijska 
Dr. sc. Tomislav Dagen i Marina Čepo, mag. iur.: Izbjeglička i migracijska kriza u Europskoj uniji... Zbornik radova Pravnog fakulteta u Splitu, god. 58, 3/2021, str. 855-873

i izbjeglička kriza iznijela je sve nedostatke takvog sustava te CEAS na temelju takvog iskustva doživljava velike promjene i prilagođava se nastalim potrebama s ciljem harmonizacije i stvaranja ujednačenih pravila u području azila i migracija.

Hrvatska je država članica koja se zbog svog položaja nametnula kao centralna stanica na tzv. "Balkanskoj ruti". Kako navodi Bačić Selanec, sustav raspodjele odgovornosti utemeljen na Uredbi Dublin III rezultirao je neravnomjernim teretima koji se nameću državama članicama EU-a (Bačić Selanec, 2013.). Države članice na istočnim i južnim granicama faktično su postale nositelji odgovornosti u ime cijele Unije. Hrvatska, kao pogranična država članica, također je u razdoblju 2015. - 2016. godine nosila breme izbjegličke i migracijske krize te se svakodnevno suočavala s brojnim izazovima koje su masovni priljevi osoba za sobom nosili. Samo u kriznom periodu, od rujna 2015. do ožujka 2016., u Hrvatsku je ušlo 658.068 ljudi, od kojih 558.724 u 2015. godini, najčešće na istočnim granicama. U navedenom razdoblju znalo se dogoditi da u Hrvatsku na istočnim granicama uđe do 10 tisuća ljudi u danu. $^{7}$

Prema podacima MUP-a, samo tijekom 2016. po Dublinskom postupku u Hrvatsku je vraćena 601 osoba, podrijetlom iz Afganistana (178), Alžira (30), Bangladeša (3), Bosne i Hercegovine (1), Egipta (1), Eritreje (10), Iraka (120), Irana (63), Kube (1), Libije (2), Maroka (22), Nigerije (4), Pakistana (2), Rusije (1), Sirije (146), Somalije (5), Šri Lanke (1), bez državljanstva (10) i nepoznatog državljanstva (1) (Hrvatski pravni centar, 2016.). Navedena vraćanja u Hrvatsku provodila su se na temelju članka 13. st. 1. Uredbe Dublin III koji propisuje odgovornost države članice u koju je osoba prvi put nezakonito ušla na teritorij EU-a. Analizirajući države iz kojih su došle osobe koje su vraćene u tijeku 2016. godine u Hrvatsku, može se zaključiti da velik broj njih zapravo pripada u skupinu migranata jer ne dolaze iz države pogođene ratom, za razliku od izbjeglica. Hrvatska je zemlja koja nije do 2016. godine imala značajan broj zahtjeva za azil, ali se 2016. godine broj takvih zahtjeva ekstremno povećao na broj od 2150, što je bilo najveće povećanje u nekoj državi članici EU-a u tom trenutku (Eurostat, 2008-2019). Većina izbjeglica i migranata koji su se priključili izbjegličkim valovima napustili su Hrvatsku na svom putu prema Zapadnoj Europi, dok je samo 39 tražitelja azila dobilo azil u Hrvatskoj. Ta je činjenica dokaz da je Hrvatska u izbjegličkoj i migracijskoj krizi bila u ulozi tranzitne zemlje, a ne zemlje odrednice za najveći broj tražitelja azila. Kako navodi Goldner Lang (Goldner-Lang, 2019.), bez obzira na to što je bila samo tranzitna zemlja, ponašanje Hrvatske i drugih zemalja na Zapadnoj mediteranskoj ruti imalo je velik utjecaj za budući razvoj CEAS-a, za što je dokaz i presuda u slučaju $A$. $S$. i Jafari i Mengesteab (Mengesteab, 2017.). Kako Čepo smatra, Dublinski sustav nije mehanizam za kontrolu masovnih izbjegličkih i migracijskih valova jer njegove odredbe inzistiraju na individualnom pristupu, dok se krizno razdoblje i problemi koji su nastali tijekom krize nalaze u pravnom vakuumu koji je stvorio sustav

7 Podaci dobiveni putem dubinskog intervjua od voditelja Ureda za nezakonite migracije Vukovarskosrijemske županije, granice na kojoj je najveći broj izbjeglica i migranata ušao u EU u kriznom razdoblju između 2015. i 2016., obavljenog 11. veljače 2019. godine. 
(Čepo, 2019.). Dublinski sustav trenutno ide prema svom četvrtom revidiranom izdanju s minimalnim promjenama, kao sustav za koji EU smatra da može uspješno odgovoriti na situacije poput migracijske, izbjegličke i sigurnosne krize. Takvo preopterećenje pograničnih država članica dovodi do izravne opasnosti te proizvodi brojne posljedice koje utječu na sigurnost određene države članice.

Kada se radi o Hrvatskoj, Sud EU-a u presudi C. K., inter alia, naglasio je kako smatra da u hrvatskom sustavu azila nema sistemskih nedostataka (C. K. v. Slovenia, 2017.). Nedostatak solidarnosti među državama članicama i nepostojanje pravedne raspodjele odgovornosti gorući je problem i ključan element neuspjeha Dublinskog sustava. Kako to smatra i Goldner Lang, Dublinski sustav s načelom "države prvog ulaska" dovodi do mehanizma prebacivanja tereta umjesto do podjele tereta zbog čega je kao takav i kritiziran kao neodrživ (Goldner Lang, 2013.). Na takav način krše se temeljna prava tražitelja azila. Takav sustav pretpostavlja da sve države članice pružaju jednake uvjete i stupanj zaštite izbjeglica na temelju svojih materijalnih i procesnih pravila, što u praksi nikada nije tako. Jednako kako je Unija razvijala sustav azila, tako je i Hrvatska mijenjala i prilagođavala svoje zakone i sustav azila kako bi odgovorila na situacije koje su se događale na njezinu teritoriju te zaštitila svoje nacionalne interese. U nastavku rada bit će prikazano kreiranje politika Hrvatske usmjerenih na normativnu zaštitu nacionalnog interesa kako bismo analizom tih politika vidjeli u kojoj je mjeri izbjeglička i migracijska kriza utjecala na njihov razvoj, kao i na zaštitu ljudskih prava izbjeglica i migranata koji su se priključili izbjegličkim valovima prema Europskoj uniji.

\section{UTJECAJ IZBJEGLIČKE I MIGRACIJSKE KRIZE IZ 2015./2016. GODINE NA RAZVOJ ZAKONSKIH I DRUGIH PRAVNO-SIGURNOSNIH OKVIRA U SVRHU ZAŠTITE TERITORIJA}

Izbjeglička i migracijska kriza iz 2015. godine svojom masovnošću i brzinom kojom se odvijala otvorila je mnoga poglavlja djelovanja javnih politika institucija EU-a zemalja članica, kao i samih zemalja koje su bile pogođene izbjegličkim i migracijskim valom. Činjenica da je Hrvatska bila na "Balkanskoj ruti" izbjegličkog i migrantskog vala i da je kroz zemlju prošlo (u tranzitnom postupku) nekoliko stotina tisuća ljudi, sustav javnih politika u Hrvatskoj morao je odgovoriti na političke odluke i politički artikulirane zahtjeve u svrhu zaštite nacionalne sigurnosti i sigurnosnih ugroza putem zakonodavnih i drugih akata pravno regulirati pitanje takve zaštite. Iako su europske javne politike pitanje azila i samo pitanje izbjegličke i migracijske krize, priljeva izbjeglica i migranata riješile obvezujućim direktivama i uredbama, a ujedno poštujući međunarodnopravne norme, ono glavno pitanje koje se nametalo u tim trenucima bilo je pitanje zaštite nacionalne sigurnosti, odnosno pitanje fizičke zaštite samog teritorija Hrvatske. Pitanje zaštite nacionalne sigurnosti i sigurnosne aspekte pojedine zemlje članice Unija je prepustila zemljama 
članicama i nacionalnim zakonodavstvima da ih urede vlastitim zakonodavnim ili drugim pravnim aktima - čl. 4. st. 2. Ugovora o Europskoj uniji, pročišćeni tekst: "Unija poštuje jednakost država članica pred Ugovorima, kao i njihove nacionalne identitete, koji su neodvojivo povezani s njihovim temeljnim političkim i ustavnim strukturama, uključujući regionalnu i lokalnu samoupravu. Ona poštuje njihove temeljne državne funkcije, uključujući osiguranje teritorijalne cjelovitosti države, očuvanje javnog poretka i zaštitu nacionalne sigurnosti. Nacionalna sigurnost posebice ostaje isključiva odgovornost svake države članice".

Iako je navedenom odredbom Ugovora o Europskoj uniji pitanje i zaštita nacionalne sigurnosti prepuštena zemljama članicama, uz to što nacionalna zakonodavstva zemalja članica imaju svu pravnu i političku dispoziciju vlastitog djelovanja po pitanju zaštite nacionalne sigurnosti, u kontekstu vremena 2015./2016. godine i masovnog priljeva izbjeglica i migranata, ipak su postojala određena međunarodnopravna ograničenja u punoj i ekstenzivnoj primjeni navedene odredbe Ugovora, a poglavito u kontekstu međunarodnopravne primjene odredbi o pravima izbjeglica. Unatoč činjenici da je odredbom Ugovora o Europskoj uniji otvoren prostor nacionalnom zakonodavnom djelovanju u sustavu zaštite nacionalne sigurnosti uz međunarodnopravna ograničenja po pitanju zaštite izbjeglica, pitanje nacionalne sigurnosti i sigurnosnih ugroza u odnosn na ostvarivanje prava izbjeglica i migranata u kontekstu zaštite nacionalne sigurnosti stavilo je pred Hrvatsku brojne pravne i sigurnosne izazove koji su se artikulirali kroz javne politike putem zakonodavnih i drugih postupanja kao mehanizama upravljanja takvom krizom. U tom smislu, ako sagledamo kontekst vremena 2015. godine i početak izbjegličke i migracijske krize, Hrvatska je istu dočekala s pravnim normama i drugim aktima iz područja nacionalne sigurnosti koji nisu u potpunosti ili u znatnoj mjeri mogli prepoznati eventualne sigurnosne ugroze ni takvo činjenično stanje koje je proizlazilo iz navedene krize. To prvenstveno sagledavamo kroz nacionalnosigurnosni strateški dokument Hrvatske u vidu Strategije nacionalne sigurnosti Hrvatske koji je donio Hrvatski sabor 19. ožujka 2002. godine (NN, 32/2002). Iako je u istom dokumentu, pod naslovom "Izazovi, rizici i prijetnje Hrvatskoj" pod točkom 33, navedeno: "Intenziviranje transnacionalnih prijetnji u regiji i izvan nje - globalni terorizam, organizirani kriminal, izbjegličke krize - neposredno i posredno će utjecati na nacionalnu sigurnost Hrvatske. Ove pojave, bez obzira je li njihovo izvorište u neposrednom okružju ili izvan njega, realni su sigurnosni rizik za Hrvatsku." Realitet događanja na granicama Hrvatske i masovnost izbjegličkog i migracijskog vala bit će ključne sigurnosne odrednice za prepoznavanje suvremenih sigurnosnih ugroza, što će za javne politike u Hrvatskoj, počevši već od 2015. godine, imati za posljedicu donošenje novih strateških akata kojima će se takve ugroze zakonodavnim i drugim pravnim sredstvima pokušati svesti na najmanju moguću mjeru.

Važnost određivanja i definiranja Strategije nacionalne sigurnosti kao elementa samostalnog djelovanja svake države članice EU-a, prepoznaje u svom radu i Bilandžić koji sve one elemente što bi ih Strategija nacionalne sigurnosti morala imati, pojmovno i definicijski određuje na način kako navodi: "Strategija nacionalne 
sigurnosti hijerarhijski je najviši i time ključni dokument u području nacionalne sigurnosti. To je 'državni vodič' za ostvarenje nacionalne sigurnosti. U njemu su, uobičajeno, prema prioritetima, navedeni ciljevi nacionalne sigurnosti i instrumenti nacionalne moći (načini, sredstva i pristupi) za ostvarenje tih ciljeva. Strategija artikulira prioritetne ciljeve te povezuje sredstva i pristupe u akcijski plan za ostvarenje ciljeva u zadanom kontekstu. Strategijama kao dokumentima, također je cilj, da kroz detaljniji prikaz strateških vizija domaćoj i inozemnoj javnosti ukažu na namjere pojedine države. Stoga su strategije nacionalne sigurnosti najprimjereniji okvir za lociranje sadržaja sigurnosti u suvremenim strateškim pristupima" (Bilandžić, 2012: 54). Navedenim definiranjem strategije nacionalne sigurnosti, Hrvatska će putem javnih politika i kroz hrvatski zakonodavni okvir u kontekstu nastupile izbjegličke i migracijske krize djelovati u skladu s europskim pravnim stečevinama i izvorima europskog javnog prava i temeljem navedenog zakonodavno normirati sigurnosne odrednice i zaštitu nacionalne sigurnosti, a poglavito u kontekstu zaštite teritorija.

U tom smislu, 2015. godine, pored navedene Strategije nacionalne sigurnosti, pravne akte koji bi se eventualno i u nekoj mjeri aktivno odnosili na zaštitu nacionalne sigurnosti i zaštitu samog teritorija predstavljat će i Zakon o azilu. ${ }^{8}$ Istim zakonom, člankom 6. stavkom 1. podstavkom 3. alineja 3, propisano kao razlog za isključenje, kaže se da se azil neće odobriti strancu "u svrhu zaštite nacionalne sigurnosti, u slučaju postojanja opravdane sumnje koja upućuje na počinjenje djela iz stavka 1. ovoga članka, nadležna sigurnosno-obavještajna agencija obavit će razgovor s tražiteljem azila te dostaviti Ministarstvu svoje mišljenje". Tražeći povezanost ili uzročnost između aktivizma javnih politika kroz predlaganje novih zakonskih okvira koji bi odgovorili na rastuću krizu, paralelno s razvojem izbjegličke krize i priljevom nekoliko stotina tisuća izbjeglica i migranata na prostor Hrvatske, hrvatsko će zakonodavstvo, u skladu s obvezama preuzetima ulaskom u EU i obvezom harmonizacije zakonodavstva s acquis EU, a paralelno s vremenom nastanka migracijske i izbjegličke krize, odgovoriti na novonastale izazove i donijeti primaran zakon koji će normirati takvo činjenično stanje. ${ }^{9}$

Stoga, a u skladu s odrednicama EU-a, Hrvatska će donijeti Zakon o međunarodnoj i privremenoj zaštiti čime Zakon o azilu prestaje važiti (NN, 70/15,127/17). U samom uvodnom tekstu zakona navodi se da se u pravni poredak Hrvatske unose direktive Europske unije, te da se u istom uređuje primjena pojedinih uredbi EU-a.

8 Zakon o azilu Republike Hrvatske, Narodne novine, br. 79/07., 88/10. i 143/13. Zakon o azilu bio je na snazi do 1. srpnja 2015. godine. Također sama ovlast postupanja i sigurnosna provjera tražitelja od strane Sigurnosno-obavještajne agencije Republike Hrvatske proizlazi i iz članka 42. Zakona o sigurnosno-obavještajnom sustavu Republike Hrvatske (Narodne novine, br. 79/06. i 105/06.) gdje se navodi: "Sigurnosna provjera provodi se i za osobe koje se primaju u hrvatsko državljanstvo i za strance u Republici Hrvatskoj čiji je boravak važan za sigurnost države"; kao i iz odredbe članka 41. Zakona o sigurnosnim provjerama (Narodne novine, br. 85/08. i 86/12.) gdje je navedeno: "Iznimno od članka 35. i 39. ovoga Zakona, kad je riječ o sigurnosnim provjerama za strance koji će boraviti ili borave u Republici Hrvatskoj i za osobe koje se primaju u hrvatsko državljanstvo, nadležna sigurnosno-obavještajna agencija dostavlja podnositelju zahtjeva samo mišljenje o postojanju ili nepostojanju sigurnosne zapreke".

9 Više o razlozima donošenja Zakona o privremenoj i međunarodnoj zaštiti u: Prijedlog Vlade RH Zakona o međunarodnoj i privremenoj zaštiti, upućenog Saboru RH, br. P.Z.E. 842, dostupno na: https:// sabor.hr/sites/default/files/uploads/sabor/2019-01-18/080829/PZE_842.pdf, pristupljeno 17. lipnja 2020. 
S obzirom na istraživanje i postavljenu tezu u ovom radu, navodimo iz članka 2. stavka 2. spomenutog Zakona uredbe koje utječu i na pitanje nacionalne sigurnosti u kontekstu migracijske politike i postupanja prema izbjeglicama: "Uredba (EU) br. 603/2013 Europskog parlamenta i Vijeća od 26. lipnja 2013. o uspostavi sustava »Eurodac« za usporedbu otisaka prstiju za učinkovitu primjenu Uredbe (EU) br. 604/2013 o utvrđivanju kriterija i mehanizama za određivanje države članice odgovorne za razmatranje zahtjeva za međunarodnu zaštitu koji je u jednoj od država članica podnio državljanin treće zemlje ili osoba bez državljanstva i o zahtjevima za usporedbu s podacima iz Eurodaca od strane tijela kaznenog progona država članica i Europola u svrhu kaznenog progona te o izmjeni Uredbe (EU) br. 1077/2011 o osnivanju Europske agencije za operativno upravljanje opsežnim informacijskim sustavima u području slobode, sigurnosti i pravde (preinaka), (SL L 180, 29. 6. 2013.)" (NN, 70/15,127/17). Značaj navedenog zakona u kontekstu zaštite nacionalne sigurnosti Hrvatske odnosi se na činjenicu da su odredbama članka 30. stavka 1. podstavka 3. propisani razlozi zbog kojih će se odbiti pravo na azil, ali ne isključuje se pravo na pristup sustavu azila, odnosno pravo na pristup teritoriju. Svaka osoba ima pravo pristupiti sustavu azila prvo pristupom teritoriju zemlje u kojoj podnosi zahtjev za azil. U kontekstu stjecanja prava na azil navedeni zakon u smislu zaštite nacionalne sigurnosti, a samim time možemo reći u krajnjem slučaju i zaštite teritorija Hrvatske, propisuje razlog u kojim slučajevima dolazi do odbijanja zahtjeva za azil, te samim time i do zaštite teritorija. Razlozi se temelje na činjenici da je tražitelj azila počinio, poticao ili na drugi način sudjelovao u izvršenju:

- "zločina protiv mira, ratnog zločina ili zločina protiv čovječnosti utvrđenog odredbama međunarodnih akata,

- teškog nepolitičkog kaznenog djela izvan Hrvatske, a prije njegova dolaska u Hrvatsku, uključujući i osobito okrutna postupanja, čak i ako su počinjena s navodnim političkim ciljem." (NN, 70/15,127/17, čl. 30. st. 1. podst. 3).

Također odredbom članka 31. stavka 1. podstavka 1. alineja 1 i 2 i člankom 31. stavkom 1. podstavkom 2. propisani su, a mogli bismo reći u smislu zaštite nacionalne sigurnosti, uvjeti kada se supsidijarna zaštita neće priznati tražitelju takve zaštite "ako postoje ozbiljni razlozi na temelju kojih se smatra da je počinio, poticao ili na drugi način sudjelovao u izvršenju:

- zločina protiv mira, ratnog zločina ili zločina protiv čovječnosti utvrđenog odredbama međunarodnih akata

- teškog kaznenog djela

- predstavlja opasnost za nacionalnu sigurnost ili javni poredak Republike Hrvatske" (NN, 70/15,127/17, čl. 31. st. 1. podst. 1. alineja 1 i 2 i čl. 31. 31. st. 1. podst. 2).

Kroz citirane odredbe zakona jasno možemo vidjeti paralelu ili samu povezanost između instituta zaštite prava izbjeglica na pristup teritoriju i zaštite samog teritorija. Bez obzira na navedene razloge zbog kojih se može odbiti zahtjev za azil, države članice dužne su poštovati načela zabrane prisilnog udaljenja ili vraćanja 
definirano Konvencijom iz 1951., EKLJP-om i člankom 6. Zakona o međunarodnoj i privremenoj zaštiti. ${ }^{10} \mathrm{U}$ daljnjem kontekstu zakonodavne zaštite nacionalnih interesa, nacionalne sigurnosti i samog teritorija Hrvatske u odnosu na izbjegličku i migracijsku krizu i sam priljev izbjegličkog vala kroz Hrvatsku, postavlja se pitanje zaštite državnih granica i pitanje što predstavlja "ne/kontrolirani" ulazak velike skupine ljudi u zemlju mimo službenih graničnih prijelaza. U tom smislu, zaštita teritorija, pa i zaštita same nacionalne sigurnosti primarna je potreba svakog društva i svakog značenja državnosti, stoga, a u smislu implementacije Zakonika o schengenskim granicama, Hrvatska će putem javnih politika donijeti Zakon o nadzoru državne granice. Donesenim zakonom, eksplicitno i nedvojbeno, njegovim člankom 3. definirat će se što predstavlja nadzor državne granice:

"(1) Nadzor državne granice, u smislu ovoga Zakona, je kontrola prelaska državne granice (u daljnjem tekstu: granična kontrola) i zaštita državne granice, a obavlja se radi:

- osiguranja nepovredivosti državne granice i državnog područja Hrvatske,

- zaštite života i zdravlja ljudi,

- sprječavanja i otkrivanja kaznenih djela i prekršaja te otkrivanja i pronalaska počinitelja istih,

- sprječavanja nezakonitih migracija i

- sprječavanja i otkrivanja drugih opasnosti za javnu sigurnost, pravni poredak i nacionalnu sigurnost.

(2) Nadzor državne granice obavlja se uzimajući u obzir procjenu rizika za unutarnju sigurnost i procjene prijetnji koje bi mogle ugroziti sigurnost granice" (NN 83/13, 27/16).

Navedene odredbe nacionalnog zakonodavstva kojima se uređuje pitanje prijelaza državne granice u potpunosti su harmonizirane sa Zakonikom o schengenskim granicama, a poglavito u kontekstu točke 6. istog gdje je navedeno: "Nadzor državne granice nije samo u interesu države članice na čijim se vanjskim granicama on provodi, već je u interesu svih država članica koje su ukinule nadzor unutarnjih granica. Nadzor državne granice trebao bi pomoći u suzbijanju nezakonitog useljavanja i trgovanja ljudima te pri sprečavanju bilo kakve prijetnje unutarnjoj sigurnosti, javnom poretku, javnom zdravlju i međunarodnim odnosima država članica". Nastavno na navedene zakonske odredbe, a u smislu pune provedbe pozitivnih propisa Europske unije (Dublin III i Zakonika o schengenskim granicama,

10 "Zabranjeno je prisilno udaljiti ili na bilo koji način vratiti državljanina treće zemlje ili osobu bez državljanstva u zemlju u kojoj bi njezin život ili sloboda bili ugroženi zbog rasne, vjerske ili nacionalne pripadnosti, pripadnosti određenoj društvenoj skupini ili zbog političkog mišljenja ili u kojoj bi mogla biti podvrgnuta mučenju, nečovječnom ili ponižavajućem postupanju, koja bi ju mogla izručiti drugoj zemlji, čime bi se narušilo načelo iz podstavka 1. i 2. ovoga stavka. Državljanin treće zemlje ili osoba bez državljanstva, koja ispunjava uvjete za odobrenje međunarodne zaštite ili joj je međunarodna zaštita odobrena, može se prisilno udaljiti ili vratiti u zemlju u kojoj ne bi bilo narušeno načelo iz stavka 1. ovoga članka, ako predstavlja opasnost za nacionalnu sigurnost ili je pravomoćno osuđena za teško kazneno djelo radi kojeg predstavlja opasnost za javni poredak". Zakon o međunarodnoj i privremenoj zaštiti, članak 6. st. 1. i 2 . 
op. a.), jasno je da je od strane zakonodavca data smjernica na koji je način dopušten pristup teritoriju državljana trećih zemalja u svrhu podnošenja zahtjeva za azilom. Unatoč navedenim odredbama, dodatni legitimitet i opravdanost zakonodavne zaštite nacionalnih interesa i zaštite nacionalne sigurnosti u pogledu migracija i prava na azil daje i samo Javno izvješće Sigurnosno-obavještajne agencije Hrvatske za 2016. godinu u kojem se navodi: "Od rujna 2015. RH se našla na ruti migracijskog vala te je do kraja godine kroz RH prošlo više od 600.000 izbjeglica i migranata. Iako je migracijski val kroz RH prošao bez većih sigurnosnih incidenata, potvrđeno je kako je poslužio i terorističkim organizacijama za prebacivanje svojih pripadnika u Europu" (Sigurnosno-obavještajna agencija, 2016: 8). Takve okolnosti i činjenice utjecat će na daljnje postupanje tijela Hrvatske, uključujući i sigurnosne službe u postupcima prihvata izbjeglica u postupcima traženja prava na međunarodnu zaštitu. Nadalje, u izbjegličkoj i migracijskoj krizi iz 2015. i 2016. godine najveću prijetnju nacionalnoj sigurnosti predstavljali su ekonomski migranti koji su iskoristili trenutak priljeva izbjeglica iz ratom zahvaćenih prostora, te su pokušali, manipulirajući sustav međunarodnopravne zaštite koja se pruža izbjeglicama, ostvariti prava ulaska na prostor Hrvatske, odnosno EU-a.

Utjecaj sigurnosnih službi u ostvarivanju prava državljana trećih država u svrhu "prava na teritorij", možemo povezati s činjenicom da rad sigurnosnih službi u tom području može proizlaziti iz/ili u svrhu "zaštite teritorija" i zaštite nacionalne sigurnosti kao posljedica primjene europskopravnih odrednica u kojima je nedvosmisleno reguliranje nacionalne sigurnosti i reguliranje pitanje zaštite nacionalne sigurnosti prepušteno nacionalnim zakonodavstvima. U konkretnom slučaju, dokaz navedenoj europskopravnoj odrednici imamo i kroz još jedan zakonodavni okvir i to kroz temeljni imigracijski propis, a to je Zakon o strancima (NN, 130/11, 74/13, 69/17 i 46/18). Navedenim zakonom i samim odredbama istoga, zakonodavac je išao s ciljem da bez obzira na činjenicu primjene humanitarnog prava i prava osoba trećih zemalja, zaštiti nacionalnu sigurnost i sam teritorij, što kao dokaz možemo tumačiti i prikazati kroz

- odredbu članka 5. stavka 1. i 2. Zakona o strancima:

"Sigurnosnu provjeru za stranaca u svrhu utvrđivanja razloga nacionalne sigurnosti provodi Sigurnosno-obavještajna agencija.

U odluci kojom iz razloga nacionalne sigurnosti ili prestaje boravak strancu ili se stranac protjeruje, navest će se zakonska odredba bez obrazlaganja razloga koji su bili odlučujući za donošenje odluke";

- kao i odredbom članka 36. stavka 1:

"Državljaninu treće zemlje koji ne ispunjava uvjete za ulazak propisan Zakonikom o schengenskim granicama može se odobriti ulazak u Hrvatsku na određenom graničnom prijelazu ako to zahtijevaju ozbiljni humanitarni razlozi, međunarodne obveze ili interes Republike Hrvatske" (NN, 130/11, 74/13, 69/17 i 46/18, čl. 5. st. 1. i 2. i čl. 36. st. 1.). 
Također navedene odrednice citiranih članaka Zakona o strancima temelj su za postupanje i samim time za godišnje Javno izvješće Sigurnosno-obavještajne agencije za 2017. godinu. U Izvješću Sigurnosno-obavještajna agencija navodi legitimitet i razloge odbijanja pružanja međunarodnopravne zaštite tražiteljima iste, kao i način na koji se može preispitivati sama zakonitost i mišljenje/postupanje Sigurnosnoobavještajne agencije u sigurnosnim provjerama tražitelja azila/međunarodne zaštite: "državna tijela nisu obvezna tražitelju a priori vjerovati, već je teret dokazivanja i uvjeravanja u istinitost navoda na tražitelju međunarodne zaštite"; "SOA u postupku provjere, u većini slučajeva, ne ocjenjuje osobe kao prijetnju nacionalnoj sigurnosti, već kod pojedinih osoba utvrđuje činjenice koje ukazuju na pouzdanost i iskrenost osobe koja traži zaštitu u Hrvatskoj", kao i "Zakonitost postupanja i opravdanost mišljenja SOA-e, u svakom individualnom slučaju, može utvrditi Upravni sud RH koji, sukladno Zakonu o tajnosti podataka, ima pravo uvida u mišljenje SOA-e. Na ovaj je način osigurana pravna zaštita tražitelja međunarodne zaštite" (Sigurnosnoobavještajna agencija, 2017: 24, 25). Nadalje, citiranim zakonskim odredbama navedenog zakona jasno se nameće premisa ispunjenosti međunarodnopravnih odrednica Hrvatske, a ujedno i zaštita teritorija, nacionalnog interesa i nacionalne sigurnosti. Također navedenim odrednicama jasno se i nedvosmisleno uz Zakon o nadzoru državne granice, a uz primjenu Zakona o sigurnosnim provjerama i Zakona o sigurnosno-obavještajnom sustavu daje značaj pravnoj utemeljenosti prava na sigurnost i zaštitu teritorija, a uz ispunjenje međunarodnopravnih odrednica koje se odnose na pitanje izbjeglica, nezakonitih migracija. U tom kontekstu, kao i uz činjenicu razvoja suvremenih sigurnosnih ugroza u regionalnom i širem značenju, proizaći će nacionalni strateški sigurnosni dokument u vidu Strategije nacionalne sigurnosti Hrvatske (NN, 73/17). Navedenom Strategijom upravo će se primijetiti suvremene ugroze izbjegličke i migracijske krize, te se u uvodnom dijelu iste navodi: "Masovna migracijska kretanja prema Europi su socijalni, razvojni, gospodarski, politički, kulturološki, zdravstveni, integracijski i sigurnosni izazov za europska društva... Jedan od izazova vezan uz migracijska kretanja je i daljnja primjena međunarodnoga prava prema migrantima i izbjeglicama" (NN, 73/17).

Iz detektirane suvremene ugroze proizašle iz masovnog migracijskog kretanja, Strategijom nacionalne sigurnosti dvotračno će se usmjeravati rješavanje takve ugroze i to na način da će se primjenjivati odrednice međunarodnog izbjegličkog prava prema izbjeglicama, uz poštovanje svih ljudskih prava i temeljnih sloboda migranata, a ujedno prikazati i nacionalnopravni i drugi mehanizmi u svrhu zaštite teritorija, nacionalne sigurnosti. Dokaz navedenom vidimo u poglavlju Strategije nacionalne sigurnosti pod nazivom "Strateški ciljevi, instrumenti i mehanizmi njihova ostvarivanja", gdje se navodi: "Hrvatska će i dalje razvijati sposobnosti integriranog upravljanja državnom granicom, kao vanjskom granicom Europske unije, ispunjavajući zahtjeve za pristupanje šengenskom prostoru. Hrvatska cee aktivno sudjelovati i inicirati zakonodavne i operativne mjere na razini EU radi jačanja ukupnih sposobnosti i spremnosti za odgovor na migracijske izazove i nadzor vanjske granice. Suzbijat će se nezakonite migracije, osobito nezakoniti prelasci državne granice i prekogranični kriminalitet, provodit će se intenzivne 
mjere vraćanja državljana trećih država koji nezakonito borave u Hrvatskoj te povećavati ukupna sigurnost Hrvatske i EU. Ojačat će se proces integracije stranaca kojima je odobrena međunarodna zaštita i boravak u Hrvatskoj" (NN, 73/17). Upravo odrednice strateških ciljeva Strategije nacionalne sigurnosti Republike Hrvatske ne proizlaze samo iz nacionalnog zakonodavstva, već, kao što je u ovom radu navedeno, i iz izvora europskog javnog prava, tj. Osnivačkih ugovora kojima se pitanje nacionalne sigurnosti i zaštite nacionalnih interesa uređuje nacionalnim zakonodavnim okvirima, kao i iz drugih akata Europske unije kojima se uređuje pitanje zaštite granica same Europske unije.

\section{ZAKLJUČAK}

Zaštita prava pristupa teritoriju ili zaštita teritorija kompleksno je pitanje u suvremenoj europskoj pravnoj i političkoj povijesti. Takva dva instituta pružanja prava $-\mathrm{s}$ jedne strane pružanje zaštite izbjeglicama i svih međunarodnih prava migrantima, a s druge strane tisućljetna zaštita nacionalnog teritorija - nedvojbeno su bili condicio sine qua non i modus operandi hrvatske javne politike kao odgovor na nastalu izbjegličku i migracijsku krizu. Tražeći kauzalni odnos između izbjegličke i migracijske krize u Uniji i hrvatskih javnih politika koje su utjecale na zakonodavnu reakciju u kontekstu pružanja primjena svih međunarodnopravnih obveza prema takvim "ranjivim skupinama", nedvojbena je činjenica da je Hrvatska, unatoč masovnosti priljeva izbjeglica i migranata od sredina ovog desetljeća, zakonodavnom "ravnotežom", tj. zakonodavnim i drugim pravnim postupcima ispunila sve međunarodnopravne i nacionalne parametre u pružanju prava takvim skupinama, a ujedno i zaštitila vlastiti teritorij. Nedvojbena je činjenica da je pravo svake države, pa i Hrvatske, brinuti se za zaštitu nacionalnih interesa i nacionalne sigurnosti, što, dakako, uključuje i zaštitu teritorija i granica. Stoga, uzimajući u obzir prava izbjeglica i međunarodnopravnu zaštitu takvih skupina, postavlja se pitanje postoji li u takvom dvostrano ovisnom odnosu opasnost od kršenja ljudskih prava. Analogija događanja sredinom prošlog desetljeća upravo je sam hrvatski zakonodavni okvir i druge pravne akte dovela u pravno ovisni odnos prema ispunjenju dvaju uvjeta i u balansiranje između prava izbjeglica i prava na pristup teritoriju, odnosno sustavu azila, sukladno međunarodnopravnim i europskopravnim odrednicama i pravu zaštite teritorija, odnosno nacionalne sigurnosti uslijed takvih događanja. Sagledavajući sam sadržaj hrvatskog zakonodavnog okvira, pozitivnih propisa, kao i postupanja javnih tijela, a možemo reći i samih sigurnosnih službi Hrvatske u postupcima stjecanja prava na azil u odnosu na pravo zaštite samog teritorija i nacionalne sigurnosti, jasno se nameće zaključak da se u ograničavanju takvih prava radi o pojedinačnim slučajevima. Dokaz navedenom možemo vidjeti upravo u zakonskim odredbama Zakona o sigurnosno-obavještajnom sustavu Hrvatske, Zakonu o sigurnosnim provjerama, kao i u samim Izvješćima SOA-e u kojim se i navodi da SOA u postupku provjere, u većini slučajeva ne ocjenjuje osobe kao prijetnju nacionalnoj sigurnosti, već kod pojedinih osoba koje traže zaštitu u 
Hrvatskoj utvrđuje činjenice koje ukazuju na njezinu pouzdanost i iskrenost. Upravo stoga, a kao dokaz hrvatskog postupanja u kontekstu vremena priljeva izbjeglica i migranata u Hrvatsku, kao i same primjene svih odrednica međunarodnog prava koje skrbe o pravu na teritorij i sva ljudska prava koja proizlaze iz toga prava, spominjemo i presudu C. K. v. Slovenia-gdje se u izreci iste navodi ... "u hrvatskom sustavu azila nema sistemskih nedostataka".

Slijedom navedenih činjenica, a stavljajući u korelaciju nastale izbjegličke i migracijske krize iz 2015./2016. godine i posljedično tome kreiranje javnih politika kao odgovor na istu, može se zasigurno zaključiti da je takva kriza dijelom utjecala na nove zakonodavne okvire i reguliranje pitanja nacionalne sigurnosti, odnosno zaštitite samog teritorija Hrvatske. Također se nameće zaključak kako je hrvatski zakonodavni okvir, unatoč činjenici zaštite nacionalne sigurnosti i zaštite teritorija, pružio primjenu svih međunarodnopravnih odrednica u području ostvarivanja prava izbjeglica i osoba iz trećih zemalja, ali je ostalo otvoreno pitanje utjecaja nezakonitih migracija, nastalih kao posljedica pokušaja manipuliranja sustavom zaštite u Europskoj uniji. Ti pokušaji zasigurno su utjecali i na polje zaštite nacionalne sigurnosti država članica i formiranje javnih politika kao odgovor na nastale okolnosti.

\section{LITERATURA}

\section{Knjige, poglavlja u knjizi i članci}

1. Bačić Selanec, N.: "Dublinska uredba i problem pograničnih država članica Europske unije", u: Župarić-Iljić, D. (ur.), Prvih deset godina razvoja sustava azila u Hrvatskoj, Centar za mirovne studije, Kuća ljudskih prava, Zagreb, 2013.

2. Bilandžić, M.: "Prema 'strategiji' nacionalne sigurnosti Europske unije? Analiza Strategije unutarnje sigurnosti Europske unije", Policija i sigurnost, Vol. 21, No 1, Zagreb, 2012.

3. Čepo, M.: "Illegal migration through the practice of the Court of Justice of the European Union and consequences for the Republic of Croatia", EU and comparative law issues and challenges series, 3, 2019.

4. Einarsen T., "The European Convention and the Notion of an Implied Right to de facto Asylum", IJRL 2, 1990., str. 361-289, u: The 1951. Convention relating to the Status of Refugees and its 1967. Protocol, A Commentary, ur. Zimmermann A., Oxford University Press, 2011., str. 47.

5. Goldner Lang, I., (2017.). "The European Union and Migration: An Interplay of National, Regional, and International Law", American journal of international law, vol. 111, str. 509-513.

6. Goldner Lang, I.: "Croatia and EU Asylum Law: Playing on the Sidelines or at the Centre of Events?", u: Stoyanova, V., Karageorgiou, E. (ed.), The New Asylum and Tranzit Countries in Europe during and in the Aftermath of the 2015/2016 Crisis, International Refugee Law Series, vol. 13, Brill Njihof, Leiden, Boston, 2019. 
Dr. sc. Tomislav Dagen i Marina Čepo, mag. iur.: Izbjeglička i migracijska kriza u Europskoj uniji... Zbornik radova Pravnog fakulteta u Splitu, god. 58, 3/2021, str. 855-873

7. Goldner Lang, I.: "Ima li solidarnosti u azilu i migracijama u Europskoj uniji?", u: Župarić-Iljić, D. (ur.), Prvih deset godina razvoja sustava azila u Hrvatskoj, Institut za migracije i narodnosti: Centar za mirovne studije: Kuća ljudskih prava, Zagreb, te: Mitsilegas, V. (2014). "Solidarity and Trust in the Common European Asylum System", Comparative Migration Studies, Vol. 2, No. 2, Amsterdam University Press, 2013.

8. Hailbronner, K.; Thym D., "Legal Framework for Entry and Border Control", u: Hailbronner, K.; Thym D. (ed.), EU Immigration and Asylum Law, A Commentary, drugo izdanje, C.H.Beck/Hart/Nomos, 2016.

9. Hathaway, C. J.; Foster, M., The Law of Refugee Status, Cambridge University Press, 2014.

10. Ineli-Ciger, M.: "Why the Directive can Play a Key Role in Solving the Migration Crisis in Europe", European Journal of Migration and Law, Volume 18: Issue 1, 2016. str. 1-33, kao i: Ineli-Ciger, M: Temporary Protection in Law and Practice, International Refugee Law Series, Vol. 10., Brill Njihoff, Leiden, Boston, 2015.

11. Pollet, K.: "A Common European Asylum System under Construction: Remaining Gaps, Challenges and Next Steps", u: Chetail, V., De Bruycker, P., Maiani, F. (ed.), Reforming the Common European Asylum System, The New European Refugee Law, Brill Nijhoff, Leiden, Boston, 2016.

12. Schuster, L., "Turning refugees into 'illegal migrants': Afghan asylum seekers in Europe", Ethnic and Racial Studies, vol. 34, Issue 8: Irregular Migrants: Policy, Politics, Motives and Everyday Lives, 2011.

13. Tsourdi, E. L.: "EU Reception Conditions: A Dignified Standard of Living for Asylum Seekers?", in: Reforming the Common European Asylum System - The New European Refugee Law, (ed.) Chetail, V., De Bruycker, P. and Maiani, F., Brill Nijhoff, Leiden, Boston, 2016.

14. Vibeke Eggli, A.: Mass Refugee Influx and the Limits of Public International Law, Martinus Nijhoff Publishers, 2002.

\section{Pravni izvori}

1. Deklaracija o teritorijalnom azilu, UNGA Res. 2312 (XXIX), 14. prosinca 1967.

2. Direktiva 2013/32/EU Europskog parlamenta i Vijeća od 26. lipnja 2013. o zajedničkim postupcima za priznavanje i oduzimanje međunarodne zaštite (preinačena) (2013.) SL L 180.

3. Direktiva 2013/33/EU Europskog parlamenta i Vijeća od 26. lipnja 2013. o utvrđivanju standarda za prihvat podnositelja zahtjeva za međunarodnu zaštitu (preinaka) (2013.) SL L 180.

4. Direktiva Vijeća 2001/55/EZ od 20. srpnja 2001. o minimalnim standardima za dodjelu privremene zaštite u slučaju masovnog priljeva raseljenih osoba te o mjerama za promicanje uravnoteženih napora država članica pri prihvatu i snošenju posljedica prihvata tih osoba (2001.) SL L 212. 
Dr. sc. Tomislav Dagen i Marina Čepo, mag. iur.: Izbjeglička i migracijska kriza u Europskoj uniji... Zbornik radova Pravnog fakulteta u Splitu, god. 58, 3/2021, str. 855-873

5. Konvencija o statusu izbjeglica od 28. srpnja 1951., Sl. 1. SFRJ, Međunarodni ugovori $15 / 1960$.

6. Konvencija za zaštitu ljudskih prava i temeljnih sloboda, pročišćeni tekst, MU 18/97, 6/99, 14/2, 13/3, 9/05, 1/06, 2/10.

7. Opća deklaracija o ljudskim pravima, usvojena i proglašena na Općoj skupštini Ujedinjenih naroda rezolucijom br. 217 /III 10. prosinca 1948. godine.

8. Povelja Europske unije o temeljnim pravima (2007.) OJ C 303.

9. Pročišćene verzije Ugovora o Europskoj uniji i Ugovora o funkcioniranju Europske unije Ugovor o Europskoj uniji (pročišćena verzija) (2007.) OJ C 202.

10. Protokol o statusu izbjeglica od 31. siječnja 1967., Sl. 1. SFRJ, Međunarodni ugovori i drugi sporazumi 15/67.

11. Strategija nacionalne sigurnosti Republike Hrvatske, Narodne novine br. 32/2002.

12. Strategija nacionalne sigurnosti Republike Hrvatske, Narodne novine, br. 73./17.

13. Uredba (EU) 2016/399 Europskog parlamenta i Vijeća o Zakoniku Unije o pravilima kojima se uređuje kretanje osoba preko granica (2016). OJ L 77.

14. Uredba (EU) br. 604/2013 Europskog parlamenta i Vijeća od 26. lipnja 2013. o utvrđivanju kriterija i mehanizama za određivanje države članice odgovorne za razmatranje zahtjeva za međunarodnu zaštitu koji je u jednoj od država članica podnio državljanin treće zemlje ili osoba bez državljanstva (preinaka) (2013.) OJ L 180.

15. Zakon o azilu Republike Hrvatske, Narodne novine, br. 79/07., 88/10. i 143/13.

16. Zakon o međunarodnoj i privremenoj zaštiti, Narodne novine, br. 70./15. i 127/17.

17. Zakon o nadzoru državne granice, Narodne novine, br. 83./13. i 27./16.

18. Zakon o sigurnosnim provjerama, Narodne novine, br. 85/08. i 86/12.

19. Zakon o sigurnosno-obavještajnom sustavu Republike Hrvatske, Narodne novine, br. 79/06. i 105/06.

20. Zakon o strancima, Narodne novine, br. 130./11., 74./13., 69./17. i 46./18.

\section{Praksa europskih sudova}

1. C-490/16 A. S. vs. Republic of Slovenia (2017.) ECLI: 2017: 585.

2. C-578/16 PPU C.K. v. Slovenia (2017.) ECLI: EU: C: 2017: 127.

3. C-646/16 Khadija Jafari and Zainab Jafari vs. Bundesamt für Fremdenwesen und Asyl (2017.) ECLI: 2017: 586.

4. C-670/16 Mangesteab (2017.) ECLI: EU: 2017: 587.

5. Chahal v. The United Kingdom (1996.) Zahtjev br. 22414/93.

6. Saadi v. Italy (2008.) Zahtjev br. 37201/06.

\section{Mrežni izvori}

1. Eurostat Statistics Explained, Asylum Statistics, dostupno na: https://ec.europa.eu/ eurostat/statistics-explained/index.php/Asylum_statistics 
Dr. sc. Tomislav Dagen i Marina Čepo, mag. iur.: Izbjeglička i migracijska kriza u Europskoj uniji... Zbornik radova Pravnog fakulteta u Splitu, god. 58, 3/2021, str. 855-873

2. Hrvatski sustav azila u 2016. godini, Nacionalni izvještaj, Hrvatski pravni centar, dostupno na: https://www.hpc.hr/wp-content/uploads/2018/06/Nacionalni-izvjestajo-sustavu-azila-2016.pdf

3. Izjava ministra unutarnjih poslova Republike Hrvatske Davora Božinovića (2018.), dostupno na: http://hr.n1info.com/Vijesti/a276241/Pravo-je-svake-drzave-da-odlucikoga-ce-pustiti-na-teritorij.html

4. Javno izvješće (2016.), Sigurnosno-obavještajna agencija, dostupno na: https://www. soa.hr/files/file/Javno-izvjesce-2016.pdf

5. Javno izvješće (2017.), Sigurnosno-obavještajna agencija, dostupno na: https://www. soa.hr/files/file/Javno-izvjesce-2017.pdf

6. Prijedlog Vlade RH Zakona o međunarodnoj i privremenoj zaštiti, upućenog Saboru RH, br. P.Z.E. 842, dostupno na: https://sabor.hr/sites/default/files/uploads/ sabor/2019-01-18/080829/PZE_842.pdf

\section{REFUGEE AND MIGRATION CRISIS - INFLUENCE AND REACH OF LEGAL ACTS FOR THE PROTECTION OF THE RIGHT TO ACCESS THE TERRITORY OR THE PROTECTION OF THE TERRITORIES?}

The refugee and migration crisis, which culminated in 2015 in the European Union, posed numerous security challenges to the Republic of Croatia, and thus normative challenges in terms of legal regulations for managing such a crisis. The relationship between the protection of the refugees when they enter the territory and the protection of the territory has certainly influenced the public policies of the Republic of Croatia, and numerous "violations" of human rights have fallen into the background for the protection of other rights. Sovereignty and protection of territory is the primary need of every society and every meaning of statehood, but does that mean that this goal should be achieved at all costs and with what consequences, ie in the causal relationship of refugee crisis and protection of territory that has supranational importance? Refugee status contains a number of rights that are protected internationally by the Convention relating to the Status of Refugees. Precisely such facts of accepting the international legal obligations of the Republic of Croatia raise the key question of whether and to what extent the international legal obligations of the Republic of Croatia, towards refugees, create a national or European security challenge. Migrants, who joined the refugee wave in 2015, are not holders of the right to asylum and must respect the set European solutions for legal entry and stay in the EU. The distinction between migrants and refugees in this crisis was the biggest problem that created numerous dangers and challenges for Member States, especially border states such as the Republic of Croatia. Therefore, this article will analyze the right to asylum and access to the asylum system in relation to the rights of Member States to protect their own territory for reasons of national security on the example of the Republic of Croatia.

Key words: refugee and migration crisis, territorial protection, legal and security challenges 